\title{
Research on resistance to sunflower broomrape: an integrated vision
}

\author{
Leonardo Velasco, Begoña Pérez-Vich and José M. Fernández-Martínez ${ }^{\star}$ \\ Institute for Sustainable Agriculture (IAS-CSIC). Alameda del Obispo s/n., 14004 Córdoba, Spain
}

Received 28 October 2015 - Accepted 16 December 2015

\begin{abstract}
Sunflower broomrape (Orobanche cumana Wallr.) parasitization on sunflower was first observed at the end of the 19th century and has continued since then jeopardizing sunflower cultivation in many areas of Europe and Asia. A distinctive characteristic of the $O$. cumana-sunflower parasitic system is that it is mainly governed by a genefor-gene interaction. This determines complete resistance in the host controlled by dominant alleles at a single locus, which facilitates the management of the resistance for hybrid seed production. But on the other hand avirulence in the parasite is also controlled by dominant alleles at a single gene. Monogenic, dominant resistance exerts a strong selection pressure on the parasite that maximizes the probability of overcoming resistance mechanisms in a short period of time. This has in fact resulted in a number of physiological races that periodically surpass all the available resistance sources. The spread of populations to new areas and the subsequent hybridization between populations is another mechanism creating genetic diversity in sunflower broomrape and allegedly recombination of avirulences genes. After more than one century of coexistence, genetic resistance to broomrape in sunflower has to be focused under an integrated approach that considers not only the characterization of resistance mechanisms in the host, but also the genetic and physiological bases of avirulence in the parasite. From the perspective of genetic resistance in sunflower, most important is not relying only on single dominant genes, but following instead pyramiding strategies. These should give priority to combining complementary mechanisms of resistance under both qualitative (vertical) and quantitative (horizontal) genetic control. These aspects are discussed in the paper.
\end{abstract}

Keywords: Avirulence genes / broomrape / genetic resistance / Orobanche cumana / sunflower

Résumé - Recherche de résistance à l'orobanche chez le tournesol : une vision intégrée. Le parasitisme de l'orobanche du tournesol (Orobanche cumana Wallr) a été observé à la fin du $19^{\mathrm{e}}$ siècle et a continué depuis lors, mettant en péril la culture du tournesol dans de nombreuses régions d'Europe et d'Asie. Une caractéristique spécifique de l'interaction O.cumana-Tournesol est qu'elle est principalement régie par une interaction gène pour gène. Elle détermine une résistance totale de l'hôte contrôlée par des allèles dominants à un seul locus, ce qui facilite la gestion de la résistance pour la production de semences hybrides. Mais d'un autre côté, l'avirulence du parasite est également contrôlée par les allèles dominants d'un seul gène. Monogénique et dominante, la résistance exerce une forte pression de sélection sur le parasite qui maximise la probabilité de surmonter les mécanismes de résistance dans un court laps de temps. Cela a en fait abouti à un certain nombre de races physiologiques d'orobanche qui contournent régulièrement toutes les sources de résistance disponibles. La propagation des populations en de nouveaux lieux et l'hybridation ultérieure entre populations est un autre mécanisme qui favorise la diversité génétique de l'orobanche du tournesol et la prétendue recombinaison des gènes d'avirulences. Après plus d'un siècle de coexistence, la résistance génétique à l'orobanche chez le tournesol doit être envisagée via une approche intégrée qui tient compte non seulement de la caractérisation des mécanismes de résistance chez l'hôte, mais aussi des bases génétiques et physiologiques de l'avirulence du parasite. Du point de vue de la résistance génétique du tournesol, le plus important est de ne pas seulement considérer les gènes dominants simples, mais davantage des stratégies pyramidales. Celles-ci devraient laisser la priorité à la combinaison de mécanismes complémentaires de résistance, via un contrôle génétique à la fois qualitatif (vertical) et quantitatif (horizontal). Ces aspects sont abordés dans cet article.

Mots clés : Gènes d'avirulence / orobanche / résistance génétique / Orobanche cumana / tournesol

^ Correspondence: jfernandezm@ias.csic.es 


\section{Introduction}

Sunflower, nowadays a major oilseed crop widely cultivated around the world, was domesticated from wild Helianthus annuus L. (Asteraceae) populations in eastern North America around 4000 years ago (Blackman et al., 2011). Orobanche cumana Wallr. is a holoparasitic plant species that parasitizes wild plants of the Asteraceae, particularly Artemisia spp., from Central Asia to South-eastern Europe (Pujadas-Salvà and Velasco, 2000). Although it is not fully understood yet how two species that evolved so geographically distant became into a parasitic association, particularly taking into account the restricted range of hosts of $O$. cumana in the wild, the main fact is that $O$. cumana started representing a problem for sunflower cultivation in Russia at the end of the 19th century, being since then named sunflower broomrape (Fernández Martínez et al., 2015). After more than one century of coexistence, sunflower broomrape remains as one of the most limiting constraints for sunflower production in Europe, Asia, and more recently parts of Africa. Indeed, sunflower broomrape infestations are continuously spreading to new areas, while simultaneously populations are becoming increasingly virulent (Fernández Martínez et al., 2015). In this review, we analyze the causes of the current situation and describe our vision about how to manage the problem from a perspective of sustainable genetic resistance.

\section{Genetics of resistance and avirulence: the gene-for-gene interaction}

Apart from O. cumana, several other species of Orobanche and the closely related genus Phelipanche cause major economic losses worldwide to a diversity of crops, e.g. O. cernua L., O. crenata Forsk., O. minor Sm., P. ramosa (L.) Pomel, and P. aegyptiaca (Pers.) Pomel (Parker, 2013). The $O$. cumana-sunflower parasitic system shows two major differences with other parasitic systems in which Orobanche/Phelipanche spp. are involved. First, sunflower is the only crop parasitized by $O$. cumana, which also has a restricted range of hosts in the wild. Contrarily, other species of economic importance of these genera have a broader range of hosts, both in agricultural systems as well as in the wild (Kreutz, 1995; Parker, 2013). Second, resistance to broomrape in sunflower is in most cases vertical, i.e. complete, race specific and controlled by single dominant genes, whilst host resistance in the other parasitic systems is in general horizontal, i.e. incomplete, non-race specific and controlled by many genes (Pérez-Vich et al., 2013). Vertical resistance is mainly governed by gene-for-gene interactions (Flor, 1971) between resistance genes in the host and the corresponding avirulence genes in the parasite. This kind of interactions is generally characterized by the existence of physiological races of the parasite, determined by dominant avirulence genes, that are controlled by dominant resistance genes in the host (Fernández-Martínez et al., 2015). Eight races of $O$. cumana, A through $\mathrm{H}$, have been reported thus far (Kaya, 2014). However, the terminology used for race identification is to some extent confusing because the same race classification is used in
Table 1. Gene-for-gene relationships, given as avirulence or virulence of the parasite, between different allelic configurations of Or5 resistance gene in sunflower and Avror5 avirulence gene in Orobanche cumana ${ }^{\mathrm{a}}$.

\begin{tabular}{lccc}
\hline & $\mathrm{Or}_{5} \mathrm{Or}_{5}$ & $\mathrm{Or} \mathrm{or} 5^{\mathrm{b}}$ & $\mathrm{or}_{5} \mathrm{Or}_{5}$ \\
\hline$A v r_{O r 5} \mathrm{Avr_{Or } 5}$ & Avirulence & Avirulence & Virulence \\
\hline$A v r_{O r 5} a v r_{O r 5}$ & Avirulence & Avirulence & Virulence \\
\hline$a v r_{O r}$ avr $r_{O r 5}$ & Virulence & Virulence & Virulence \\
\hline
\end{tabular}

${ }^{a}$ From Rodríguez-Ojeda, Pineda-Martos et al., 2013. ${ }^{\mathrm{b}}$ Hypothesized.

different geographical areas without the corresponding comparative studies. For example, we have identified marked differences between populations classified as race F from Spain and Romania for virulence against a set of differential lines (unpublished results).

Genetic studies on resistance to broomrape in sunflower have confirmed in most cases control of the trait by single dominant genes, as expected for a gene for gene interaction. This has been reported for races E (Vranceanu et al., 1980; Ish-Shalom-Gordon et al., 1993; Lu et al., 2000; PérezVich et al., 2004; Sukno et al., 1999), F (Pacureanu-Joita et al., 2004; Pérez-Vich et al., 2002), and G (Velasco et al., 2012). Full demonstration of the occurrence of a gene-forgene interaction in the $O$. cumana-sunflower was provided by Rodríguez-Ojeda, Pineda-Martos et al. (2013), who showed that $O$. cumana race $\mathrm{E}$ avirulence in presence of the resistance gene $\operatorname{Or} 5$ was inherited as a single dominant gene. The genefor-gene relationships between the dominant resistance gene Or 5 in sunflower, conferring resistance to broomrape race E but not to race F, and the avirulence gene Avr ${ }_{O r 5}$, determining avirulence in presence of the dominant $\operatorname{Or} 5$ gene, are shown in Table 1. Studies focused on developing molecular markers for avirulence genes in $O$. cumana plants are underway. They require the development of lines from populations of several races, crosses between them, selfing segregating broomrape populations (Fig. 1) and evaluation of avirulence/virulence reactions against differential lines. In spite of the difficulty of these studies, markers for avirulence genes are anticipated as extremely powerful tools for accurate race classification of $O$. cumana populations and individual plants.

In addition to the gene-for-gene interaction, not reported for other parasitic systems involving other Orobanche/ Phelipanche spp., sources of genetic resistance to $O$. cumama with other modes of inheritance have been reported as well (Fernández-Martínez et al., 2015).

\section{Sources of resistance in sunflower}

Genetic sources of resistance to sunflower broomrape have been developed in most cases after evaluation of resistance in germplasm conserved in gene banks, including accessions of cultivated sunflower as well as accessions of wild Helianthus spp. (Seiler and Jan, 2014). Since commercial sunflower cultivation is mainly based on $F_{1}$ hybrid cultivars, the use of monogenic, dominant resistance to broomrape has facilitated the rapid development of resistant hybrids, due to the facility of identifying genotypes carrying the dominant allele 


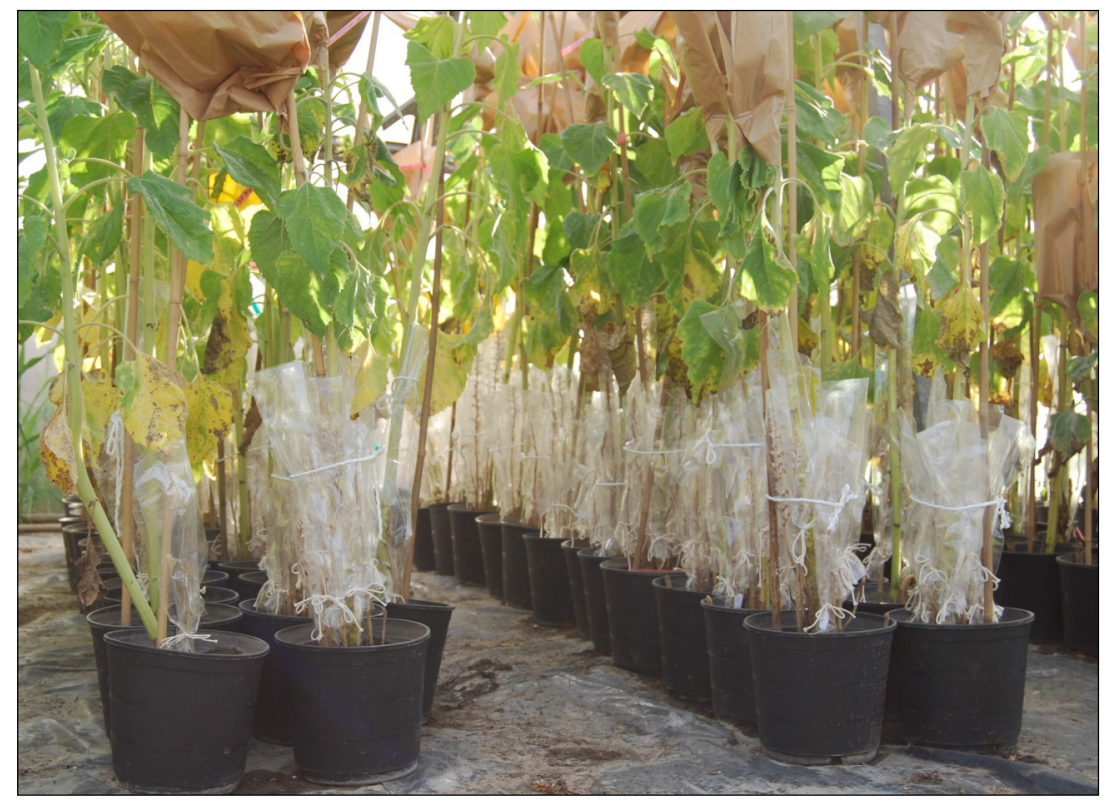

Fig. 1. Selfing individual plants from segregating sunflower broomrape populations for genetic study of avirulence genes.

at each backcross generation. Additionally, dominant alleles need to be introgressed only in one of the parents of the hybrid (Fernández-Martínez et al., 2009). But on the other hand, the continuous use of single dominant genes of resistance has facilitated the development and rapid spread of new races of the parasite, demanding a new cycle of identification of genes of resistance to the new race and their introgression into elite lines (Fernández-Martínez et al., 2015).

Sources of resistance to the first broomrape populations (race A) observed in the former USSR were identified as early as in the 1910's (Gorbachenko et al., 2011). Russian breeders made extensive use of interspecific hybridization with $H$. tuberosus, not only for resistance to broomrape but also as a source of resistance genes for several diseases and pests (Skoric, 2012). The use of interspecific hybridization together with breeding methods based on recurrent selection, such as the "method of reserves" (Pustovoit, 1967) created a reservoir of resistance genes that has been one of the main sources for breeding for broomrape resistance until recently (FernándezMartínez et al., 2004). Nevertheless, identifying resistance to the most virulent races in germplasm of cultivated sunflower has become increasingly difficult, which has demanded the identification of resistance sources in wild Helianthus spp. and their introgression into cultivated sunflower.

The genus Helianthus encompasses both annual and perennial species. The largest germplasm collection of wild Helianthus spp., maintained by the USDA-ARS National Plant Germplasm System, contains accessions from 14 annual and 39 perennial species (Seiler and Jan, 2014). Whereas annual species are diploid $(2 n=34)$, perennial species include diploid, tetraploid $(2 n=68)$, and hexaploid $(2 n=102)$ species (Jan and Seiler, 2007). Most of the perennial species are immune to broomrape, while resistance in annual species is scarce, particularly to the most virulent races. For example, Ruso et al. (1996) and Fernández-Martínez et al. (2000) evaluated wild Helianthus populations for resistance to Spanish races $\mathrm{E}$ and F, respectively. They found resistance to both races in 29 perennial species, while only four annual species showed some resistance to both races. Christov (2013) reported resistance to Bulgarian race $\mathrm{G}$ in 5 annual and 12 perennial species.

Interspecific hybridization and introgression of resistance genes from wild annual Helianthus spp. is not particularly complex. Velasco et al. (2012) identified resistance to broomrape race $\mathrm{G}$ in an accession of $H$. debilis ssp. tardiflorus that was successfully introgressed into cultivated sunflower. The authors reported that the trait was controlled by dominant alleles at a single locus. Figure 3 shows the flowers of a resistant accession of $H$. debilis and the $\mathrm{F}_{1}$ plant from its cross with cultivated sunflower. Contrarily to annual species, hybridization with perennial species and introgression of resistance genes into cultivated sunflower is a task of major difficulty for two main reasons. First, the introgression itself requires a long process that involves embryo rescue in early generations, chromosome doubling in some cases, and several backcross generations just to get rid of chromosomes of the wild species (Jan and Fernández-Martínez, 2002). Figure 2 summarizes this process in the case of a tetraploid species. Selection for broomrape resistance during this process may be useful in the case of dominant resistance, otherwise resistance gene(s) can be lost unless high numbers of plants are maintained at all steps of the process. A second drawback of using perennial species as a source of genes of resistance to broomrape is the difficulty of recovering good agronomic characteristics and high oil content, particularly when the introgressed progenies carry large introgression fragments (Breton et al., 2010).

\section{Genetic diversity of the parasite}

Understanding the genetic diversity of $O$. cumana, the structure of its populations and how different populations can 


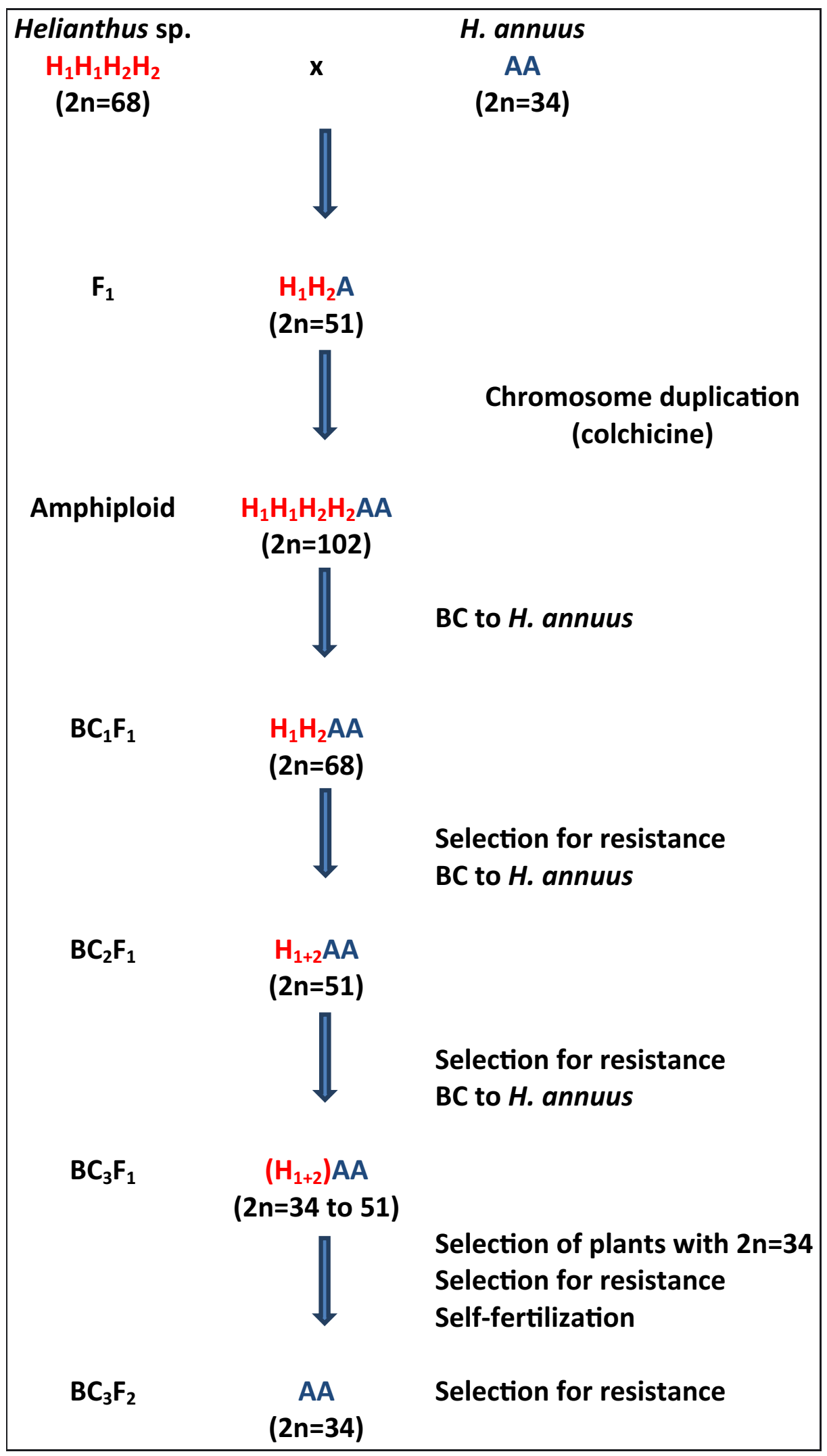

Fig. 2. Schematic representation of interspecific hybridization between a tetraploid Helianthus sp. and cultivated H. annuus. 


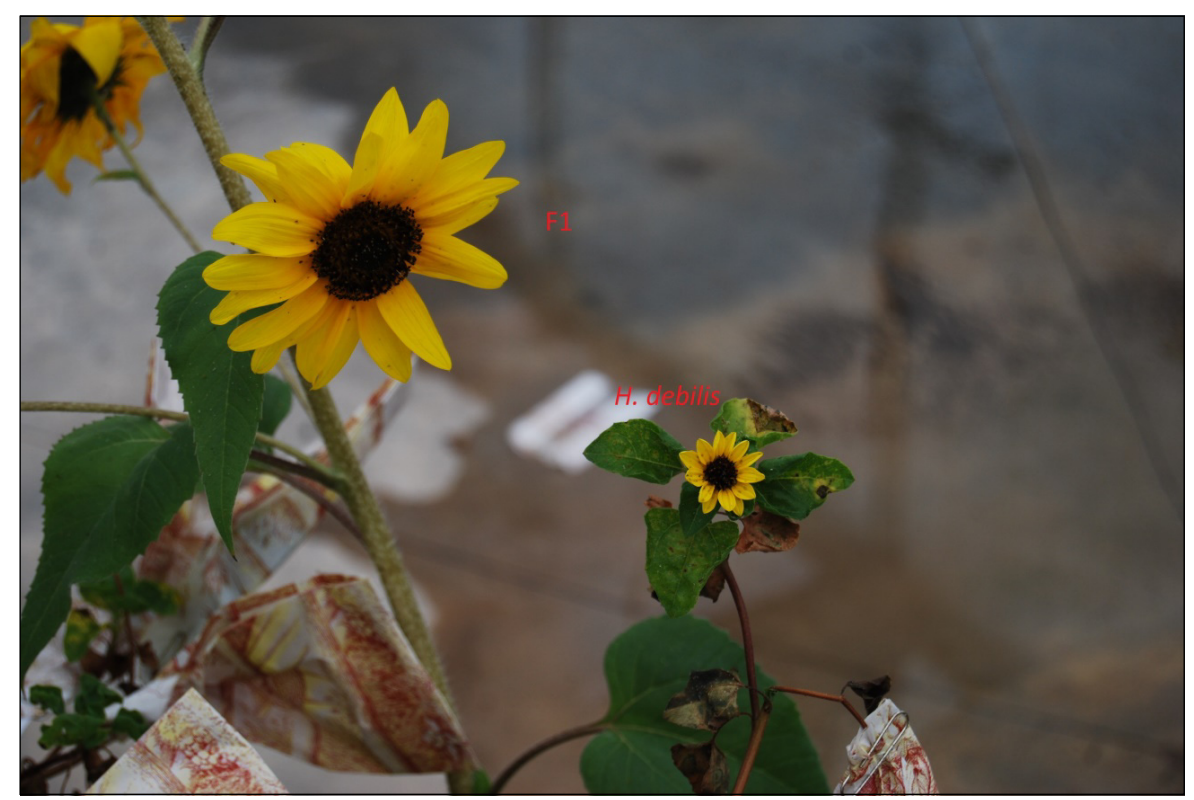

Fig. 3. Flowers of the wild annual species $H$. debilis and the $\mathrm{F}_{1}$ generation from its cross with cultivated sunflower.

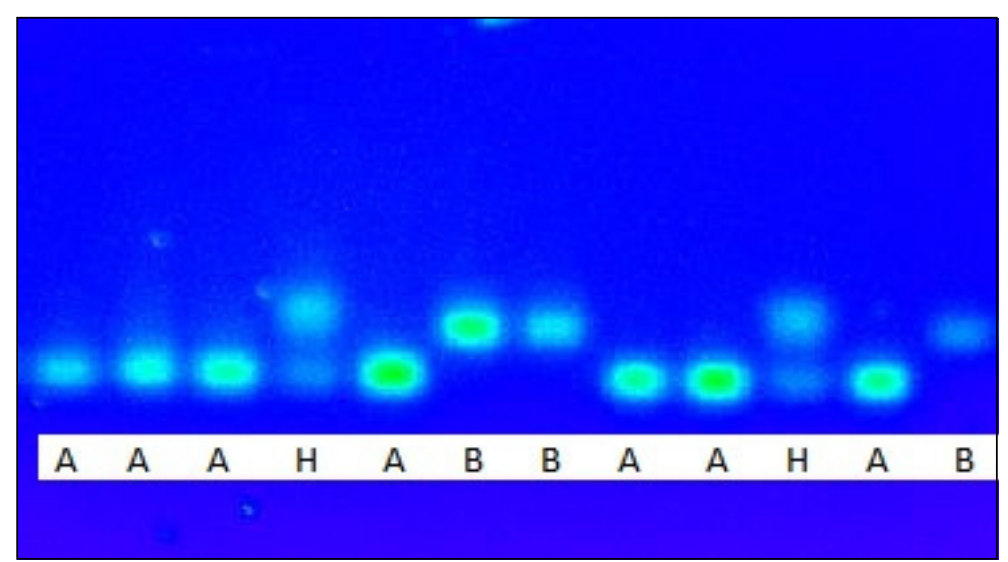

Fig. 4. Allelic variation at the Ocum-197 SSR loci in 12 individual plants of a $O$. cumana population collected in Sevilla, Spain. A = allele of Southern Spain gene pool; B = allele of Central Spain gene pool; $\mathrm{H}$ = heterozygote.

interact is of paramount importance to understand its interaction with sunflower. Unfortunately, no studies at a global scale have been conducted on the genetic diversity of the parasite. A study conducted in Spain, where the species is not found in the wild but only as weedy forms in sunflower crops, revealed the presence of two separate gene pools, one in the central part of the country and another one in the south. The two gene pools are very distant genetically and contain very low internal variability. This was interpreted as two separate introductions, with a "founder effect" being the main reason for the extremely low genetic diversity within each gene pool (Pineda-Martos et al., 2013). An important observation in that study was that both genetically distant gene pools are starting to get in contact in some areas, which is creating new populations with a spectacular increase of genetic diversity. This is not only due to the presence of plants of both genetic pools in the same population, but mainly to the fact that they are intercrossing and subsequently producing segregating progenies with large genetic diversity. Figure 4 shows the allelic variation for a microsatellite (SSR) marker discriminant for the two gene pools in 12 individual plants of one of those populations, collected in Sevilla province, Southern Spain. It can be observed the presence of plants having the allele of Southern Spain (A), Central Spain (B), and two heterozygotes. Whether the increased genetic diversity may have consequences for the virulence of the populations is something that is currently being investigated.

Our observation of natural hybridization between plants of a population under field conditions contributes to clarify one of the mechanisms of generation of genetic diversity in this species. In fact, the occurrence of cross pollination in $O$. cumana was demonstrated experimentally by RodríguezOjeda, Fernández-Martínez et al. (2013), who found average rates of cross-fertilization of $21.5 \%$ and $28.8 \%$ in two experiments. These rates, obtained following an experimental design, are probably higher that those occurring in crop fields, but they 


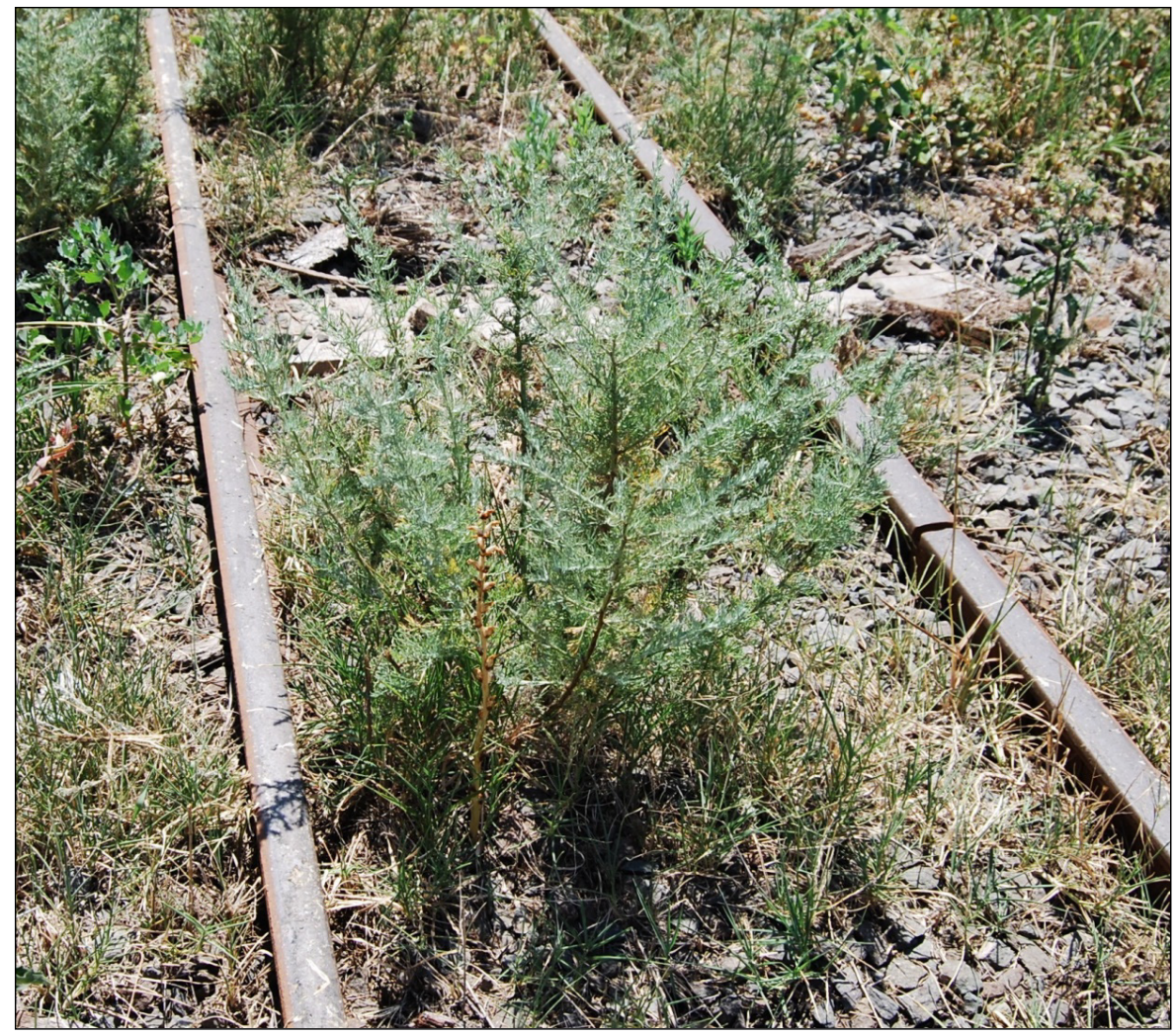

Fig. 5. Orobanche cumana growing in the wild on Artemisia maritima in the Black Sea Coast of Bulgaria.

revealed for the first time that $O$. cumana is not an strictly self-fertilized species as reported previously in the literature. It is noteworthy that in the mentioned study we also identified small insects of the Halictidae family carrying out pollen transfer between plants.

Gene transfer has also been observed between $O$. cumana populations parasitizing sunflower in agricultural fields and populations parasitizing wild plants (Fig. 5) in the natural distribution area of this species (Pineda-Martos et al., 2014). In that study, conducted in the Black Sea Coast of Bulgaria, we could not ascertain whether gene transfer was mainly due to seed or pollen movement between populations. In any case, gene transfer from populations parasitizing wild plants to weedy populations appears as an additional mechanism creating genetic diversity in the latter populations, which may contribute to their ability to overcome resistance barriers. Gene transfer in the opposite direction may also have an important ecological significance due to the potential movement to the wild of new alleles of virulence developed under the selection pressure of agricultural fields.

Genomic and transcriptomic research is also important to understand the interactions of $O$. cumana and sunflower (Muños et al., 2015). Omic approaches will be particularly relevant to identify key genes in the different stages of parasitization and how they overcome sunflower defensive barriers. Complete sequencing the $O$. cumana genome will be also extremely useful to identify avirulence genes, to understand genetic changes leading to increased virulence, and to characterize allelic differences that define what we nowadays call races of the parasite.

\section{Strategies for sustainable resistance}

The use of a reduced number of sources of resistance to sunflower broomrape, most of them monogenic and dominant, has promoted a continuous development of increasingly virulent forms of the parasite. This has led breeding companies to devote huge efforts to identify new resistance genes and to incorporate them into commercial hybrids. Nowadays, broomrape is spreading to areas where it was not present before, e.g. Northern Spain (Pineda-Martos et al., 2013), France (Jestin et al., 2014), and Tunisia (Amri et al., 2012), while very virulent populations classified as races $\mathrm{G}$ and $\mathrm{H}$ are becoming prevalent in some areas (Antonova, 2014; Pacureanu, 2014). This situation requires a shift in the strategy of broomrape control by means of genetic resistance. In spite of the availability of vertical resistance sources that still control most of the broomrape populations, their use alone will contribute to create new races as well as to their rapid spread. Instead, pyramiding major genes controlling different mechanisms of resistance should be considered as a first strategy towards sustainable genetic control of broomrape. Major genes are easily introgressed into elite lines with the aid of molecular markers, which in turn are easily developed for this kind of genes. Additionally, genes with minor effect should be also considered in any pyramiding strategy, as they will contribute to the durability of resistance, particularly if their mode of action occurs at the initial stages of parasitization or if it is complementary to the mode of action of major resistance genes.

The development of sustainable resistance strategies will require strong research support. A key research area is the 
identification and characterization of new major resistance genes, either dominant or recessive, in sunflower and wild Helianthus spp. germplasm. Characterization of the new resistance sources should include the study of the mode of inheritance, mechanisms of resistance involved, and precise tagging of the genes to facilitate the development of accurate molecular markers. Identifying minor QTL and their association with resistance mechanisms is also important. Previous studies have shown that accumulation of minor QTL can result into complete resistance to broomrape in sunflower (Pérez-Vich et al., 2004).

From the parasite side, characterization of its global genetic diversity in both weedy and wild population will contribute to understand genetic flows and the mechanisms of spatial distribution. One of the most important research areas, in which we are working currently, is the identification of avirulence genes in broomrape and how they interact with resistance genes in the parasite. Developing molecular markers for avirulence genes will allow accurate classification of individual plants into virulence groups and subsequently investigating the heterogeneity of populations for virulence. Previous studies have shown that broomrape populations may contain individuals with ability to overcome a new resistant gene even before cultivation of hybrids carrying the gene, which will act filtering the population and thus producing a rapid spread of the virulent genotype (Molinero-Ruiz et al., 2008). The availability of genomic and transcriptomic information from ongoing projects (Muños et al., 2015) will facilitate the development of molecular tools for a wide diversity of studies on sunflower broomrape.

Finally, it has to be mentioned that the strategies for sustainable resistance that we have discussed above may be combined with other strategies within an integrated management of the parasite. Currently, breeding companies are combining genetic resistance to broomrape with genetic tolerance to herbicides (Alonso, 2014; Szalay, 2014). Additionally, following recommended cultural practices can contribute to reduce seedbank population and to limit the spread of virulent populations of the parasite to new areas (Fernández-Martínez et al., 2015).

Acknowledgements. Authors' research on sunflower broomrape is being supported by research project AGL2014-53886-P funded by the Spanish Ministry of Economy and Competitiveness and European Union FEDER funds.

Disclosure. Conflict of interest: none.

\section{References}

Alonso LC. 2014. Syngenta's integrated sunflower broomrape management program. In: Proc. 3rd Int. Symp. on Broomrape in Sunflower, Córdoba, Spain, 3-6 June 2014. Paris, France: International Sunflower Association, pp. 237-252.

Amri M, Abbes Z, Ben Youssef S, Bouhadida M, Ben Salah H, Kharrat M. 2012. Detection of the parasitic plant Orobanche cumana on sunflower (Helianthus annuus L.) in Tunisia. Afr. J. Biotechnol. 11: 4163-4167.
Antonova T. 2014. The history of interconnected evolution of Orobanche cumana Wallr. and sunflower in the Russian Federation and Kazakhstan. In: Proc. 3rd Int. Symp. on Broomrape in Sunflower. Córdoba, Spain, 3-6 June 2014. Paris, France: International Sunflower Association, pp. 57-64.

Blackman BK, Scascitelli M, Kane NC, et al. 2011. Sunflower domestication alleles support single domestication center in eastern North America. Proc. Natl. Acad. Sci. USA 108: 14360-14365.

Breton C, Serieys H, Bervillé A. 2010. Gene transfer from wild Helianthus to sunflower: topicalities and limits. OCL 17: 104-114.

Christov M. 2013. Contribution of interspecific and intergeneric hybridization to sunflower breeding. Helia 58: 1-18.

Fernández-Martínez J, Melero-Vara JM, Muñoz-Ruz J, Ruso J, Domínguez J. 2000. Selection of wild and cultivated sunflower for resistance to a new broomrape race that overcomes resistance to Or5 gene. Crop Sci. 40: 550-555.

Fernández-Martínez JM, Pérez-Vich B, Akhtouch B, et al. 2004. Registration of four sunflower germplasm lines resistant to race F of broomrape. Crop Sci. 44: 1033-1034.

Fernández-Martínez JM, Pérez-Vich B, Velasco L. Sunflower. In: Vollmann J, Rajcan I, eds., Oil Crops. New York: Springer, 2009, pp. 155-232.

Fernández-Martínez JM, Pérez-Vich B, Velasco L. Sunflower broomrape (Orobanche cumana Wallr.). In: Martínez-Force E, Dunford NT, Salas JJ, eds. Sunflower Oilseed. Chemistry, Production, Processing and Utilization. Champaign, IL (USA): AOCS Press, 2015, pp. 129-156.

Flor HH. 1971. Current status of the gene-for-gene concept. Ann. Rev. Phytopathol. 9: 275-296.

Gorbachenko FI, Usatenko TV, Gorbachenko OF. 2011. Results of sunflower breeding in resistance to broomrape on Don. Helia 54: 9-18.

Ish-Shalom-Gordon N, Jacobsohn R, Cohen Y. 1993. Inheritance of resistance to Orobanche cumana in sunflower. Phytopathology 83: $1250-1252$.

Jan CC, Fernández-Martínez JM. 2002. Interspecific hybridization, gene transfer, and the development of resistance to broomrape race $\mathrm{F}$ in Spain. Helia 36: 123-136.

Jan CC, Seiler G. Sunflower. In: Singh RJ, ed., Oilseed crops. Genetic resources, chromosome engineering, and crop improvement. Boca Raton, FL, USA: CRC Press, 2007, Vol. 4, pp. 103165.

Jestin C, Lecomte V, Duroueix F. 2014. Current situation of sunflower broomrape in France. In: Proc. 3rd Int. Symp. on Broomrape in Sunflower. Córdoba, Spain, 3-6 June 2014. Paris, France: International Sunflower Association, pp. 28-31.

Kaya Y. 2014. Current situation of sunflower broomrape around the world. Current situation of sunflower broomrape around the world. In: Proc. 3rd Int. Symp. on Broomrape in Sunflower. Córdoba, Spain, 3-6 June 2014. Paris, France: International Sunflower Association, pp. 9-18.

Kreutz CAJ. Orobanche: the European broomrape species. I. Central and Northern Europe. Maastricht: Stichting Natuurpublicaties Limburg, 1995.

Lu YH, Melero-Vara JM, García-Tejada JA, Blanchard P. 2000. Development of SCAR markers linked to the gene Or 5 conferring resistance to broomrape (Orobanche cumana Wallr.) in sunflower. Theor. Appl. Genet. 100: 625-632.

Molinero-Ruiz ML, Pérez-Vich B, Pineda-Martos R, Melero-Vara JM. 2008. Indigenous highly virulent accessions of the sunflower root parasitic weed Orobanche cumana. Weed. Res. 48: 169-178. 
Muños S, Pérez-Vich B, Simier P, et al. 2015. Towards the genome sequence of Orobanche cumana. In 13th World Congress on Parasitic Plants, 5-10 July 2015, Kunming, China. Book of Abstracts, p. 89.

Pacureanu, M.J. 2014. Current situation of sunflower broomrape (Orobanche cumana Wallr.) in Romania. In: Proc. 3rd Int. Symp. on Broomrape in Sunflower, Córdoba, Spain, 3-6 June. Paris, France: International Sunflower Association, pp. 39-43.

Pacureanu M, Veronesi C, Raranciuc S, Stanciu D. 2004. Parasitehost plant interaction of Orobanche cumana Wallr. (Orobanche cernua Loefl) with Helianthus annuus. In: Proc. 16th Int. Sunflower Conf., Fargo, ND, USA, Aug 29-Sept 2, 2004. Paris, France: International Sunflower Association, pp. 171-177.

Parker C. The parasitic weeds of the Orobanchaceae. In: Joel DM, Gressel J, Musselman LJ, eds., Parasitic Orobanchaceae. New York: Springer, 2013, pp. 313-344.

Pérez-Vich B, Akhtouch B, Muñoz-Ruz J, Fernández-Martínez JM, Jan CC. 2002. Inheritance of resistance to a highly virulent race $\mathrm{F}$ of Orobanche cumana Wallr. in a sunflower line derived from interspecific amphiploids. Helia 36: 137-144.

Pérez-Vich B, Akhtouch B, Knapp SJ, et al. 2004. Quantitative trait loci for broomrape (Orobanche cumana Wallr.) resistance. Theor. Appl. Genet. 109: 92-102.

Pérez-Vich B, Velasco L, Rich PJ, Ejeta G. Marker-assisted and physiology-based breeding for resistance to root parasitic Orobanchaceae. In: Joel DM, Gressel J, Musselman LJ, eds., Parasitic Orobanchaceae. New York: Springer, 2013, pp. 369391.

Pineda-Martos R, Velasco L, Fernández-Escobar J, FernándezMartínez JM, Pérez-Vich B. 2013. Genetic diversity of Orobanche cumana populations from Spain. Weed. Res. 53: 279 289.

Pineda-Martos R, Pujadas-Salvà AJ, Fernández-Martínez JM, Stoyanov K, Velasco L, Pérez-Vich B. 2014. The genetic structure of wild Orobanche cumana Wallr. (Orobanchaceae) populations in Eastern Bulgaria reflects introgressions from weedy populations. Sci. World. J. 150432.

Pujadas-Salvà AJ, Velasco L. 2000. Comparative studies on Orobanche cernua L. and O. cumana Wallr. (Orobanchaceae) in the Iberian Peninsula. Bot. J. Linn. Soc. 134: 513-527.
Pustovoit VS. 1967. Handbook of selection and seed growing of oil plants. Moscow, Russia: Kolos (In Russian, English translation from National Information Service. US Dept. of Commerce, Springfield, VA, USA).

Rodríguez-Ojeda MI, Pineda-Martos R, Alonso LC, et al. 2013. A dominant avirulence gene in Orobanche cumana triggers $O r 5$ resistance in sunflower. Weed. Res. 53: 322-327.

Rodríguez-Ojeda MI, Fernández-Martínez JM, Velasco L, PérezVich B. 2013. Extent of cross-fertilization in Orobanche cumana Wallr. Biol. Plant. 57: 559-562.

Ruso J, Sukno S, Domínguez-Gimenez J, Melero-Vara JM, Fernández-Martínez J. 1996. Screening wild Helianthus species and derived lines for resistance to several populations of Orobanche cernua. Plant Dis. 80: 1165-1169.

Seiler GJ, Jan CC. 2014. Wild sunflower species as a genetic resource for resistance to sunflower broomrape (Orobanche cumana Wallr.). Helia 61: 129-139.

Skoric D. The genetics of sunflower. In: Skoric D, Sakac Z, Eds., Sunflower genetics and breeding. Novi Sad, Serbia: Serbian Academy of Sciences and Arts, 2012, pp. 1-163.

Sukno S, Melero-Vara JM, Fernández-Martínez JM. 1999. Inheritance of resistance to Orobanche cernua Loefl. in six sunflower lines. Crop Sci. 39: 674-678.

Szalay R. 2014. Towards sustainable development solution in broomrape management. In: Proc. 3rd Int. Symp. on Broomrape in Sunflower, Córdoba, Spain, 3-6 June 2014. Paris, France: International Sunflower Association, p. 236.

Velasco L, Pérez-Vich B, Yassein AM, Jan CC, Fernández-Martínez JM. 2012. Inheritance of resistance to broomrape (Orobanche cumana Wallr.) in an interspecific cross between Helianthus annuus and Helianthus debilis ssp. tardiflorus. Plant Breed. 131: 220-221.

Vranceanu AV, Tudor VA, Stoenescu FM, Pirvu N. 1980. Virulence groups of Orobanche cumana Wallr. differential hosts and resistance sources and genes in sunflower. In: Proc. 9th Int. Sunflower Conf., Torremolinos, Spain, 8-13 July. Paris, France: International Sunflower Association, pp. 74-80.

Cite this article as: Leonardo Velasco, Begoña Pérez-Vich, José M. Fernández-Martínez. Research on resistance to sunflower broomrape: an integrated vision. OCL 2016, 23(2) D203. 